\title{
Autocrine IL-6 mediates pituitary tumor senescence
}

Research Paper

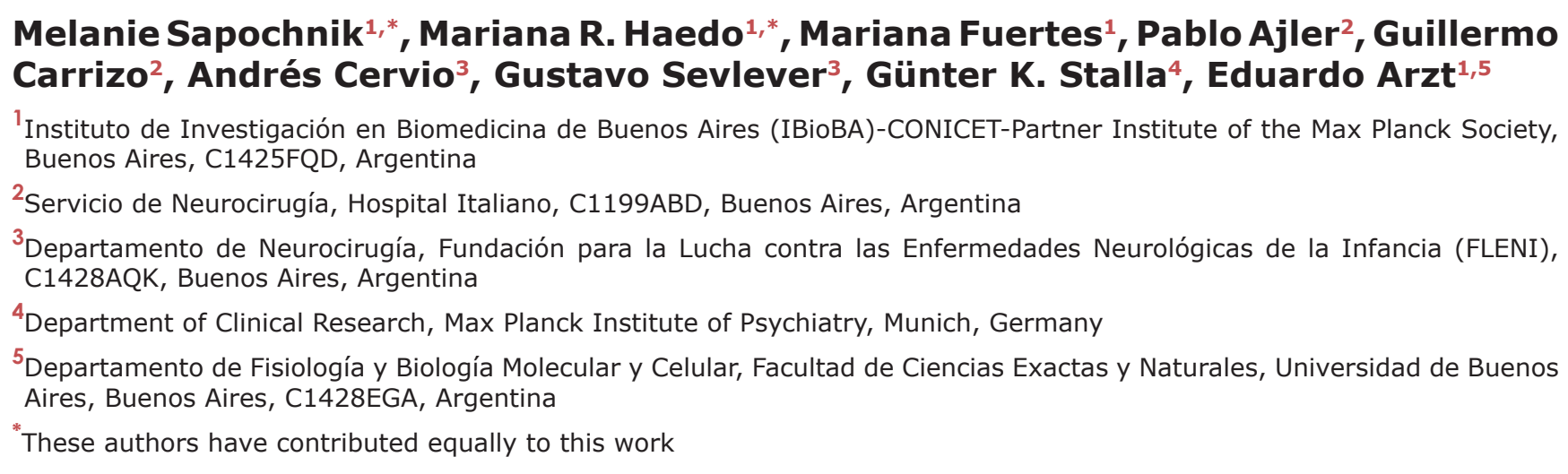

Correspondence to: Eduardo Arzt, email: earzt@ibioba-mpsp-conicet.gov.ar

Keywords: senescence, IL-6, pituitary tumor, benign tumor, autocrine

Received: April 29, $2016 \quad$ Accepted: November 6, $2016 \quad$ Published: November 24, 2016

\section{ABSTRACT}

Cellular senescence is a stable proliferative arrest state. Pituitary adenomas are frequent and mostly benign, but the mechanism for this remains unknown. IL- 6 is involved in pituitary tumor progression and is produced by the tumoral cells. In a cell autonomous fashion, IL-6 participates in oncogene-induced senescence in transduced human melanocytes. Here we prove that autocrine IL-6 participates in pituitary tumor senescence. Endogenous IL-6 inhibition in somatotroph MtT/S shRNA stable clones results in decreased SA- $\beta$-gal activity and $p 16^{\mathrm{INK} 4 \mathrm{a}}$ but increased $\mathrm{pRb}$, proliferation and invasion. Nude mice injected with IL-6 silenced clones develop tumors contrary to $\mathrm{MtT} / \mathrm{S}$ wild type that do not, demonstrating that clones that escape senescence are capable of becoming tumorigenic. When endogenous IL-6 is silenced, cell cultures derived from positive SA- $\beta$-gal human tumor samples decrease the expression of the senescence marker. Our results establish that IL- 6 contributes to maintain senescence by its autocrine action, providing a natural model of IL- 6 mediated benign adenoma senescence.

\section{INTRODUCTION}

Cellular senescence is a state of stable proliferative arrest in $\mathrm{G}_{1}$ phase of the cell cycle through activation of the $\mathrm{p} 53 / \mathrm{p} 21^{\mathrm{Cip} 1}$ and $\mathrm{pRb} / \mathrm{p} 16^{\mathrm{INK} 4 \mathrm{a}}$ signaling pathways, including alterations in the phenotype of the cells. Senescence is induced by several cellular events such as telomere dysfunction, cellular stress, DNA and chemical damage or oncogene activation [1-3]. Senescence includes several different effector mechanisms and has been recently described not only as a static endpoint, but also as a dynamic process that ends in phenotypic changes $[4,5]$. This feature is more relevant in acute types of senescence, such as oncogene-induced senescence (OIS), where the initial proliferative-mitotic state mimics transformation, but is gradually replaced by senescence [6]. Thus, OIS represents the action of senescence as a tumor-suppresive mechanism [7, 8]. OIS has been implicated in the arrest of several types of benign tumors, such as human and murine melanocytic nevi $[9,10]$, human dermal neurofibromas [11] and human schawnnomas [12], but not in malignant adenocarcinomas.

Pituitary adenomas are usually benign, nonmetastatic and monoclonal tumors formed by adenopituitary gland cells, which cause small local lesions and display a slow growth rate [13-15]. The mechanisms for the particular benign feature of these adenomas are still not clear. Since pituitary adenomas have exhibited stable growth after decades of observation [16] and senescence occurs in early stages of benign but not in malignant tumors, it could be proposed as a major mechanism to understand its benign nature [17]. Pituitary adenoma 
senescent phenotype [18, 19] and the involvement of the oncogene pttg [18], have been observed. Thus, initial pituitary tumor senescence may circumvent proproliferative signals, contributing to stop cell proliferation, but preserving important homeostatic pituitary functions $[14,17,20]$.

Normal pituitary cells are under the auto-/ paracrine control of several growth factors. Changes in the expression levels and/or the function of these molecules have been described to contribute to pituitary adenoma development [21]. Altered levels of cytokines and growth factors and their corresponding receptors, such as transforming growth factor alfa and beta protein families, epidermal growth factor, fibroblast growth factor family, bone morphogenetic protein 4 and interleukin 6 (IL-6)/glycoprotein 130 family, has been observed in pituitary tumors [21-24]. In particular, it is known that IL-6 participates in pituitary tumor development and progression. It is produced by the tumoral cells but is also secreted to the normal or adenoma cells by folliculo stellate (FS) cells, which mix up with the normal pituitary cells and further surround the pituitary tumors [25-28]. In pituitary adenoma cultures, cells other than FS cells are responsible for IL-6 production [29]. It has been shown that IL-6 inhibits normal pituitary cell proliferation and has opposite effects in normal and tumoral pituitary cells $[30,31]$.

A previous report [32] showed that IL-6 plays an important role in OIS induction and maintenance in transduced human melanocytes, acting in a cellautonomous mode to allow OIS. Autocrine IL-6 acts to regulate OIS and the same senescent cells produce an IL-6 pool that acts promitogenically in a paracrine way, indicating that IL-6 can function as an autocrine or paracrine tumorigenic factor. Taking into account that IL-6 participates in the progression of pituitary tumors, and its role in OIS, this cytokine appears as a candidate for an autocrine/paracrine regulator of pituitary adenoma control $[17,30,33]$.

In the present work we demonstrate that IL-6 participates in pituitary tumoral senescence. Our findings establish that IL-6 contributes to maintain senescence by its autocrine action, providing a natural model of IL-6 mediated tumor senescence, which may contribute to explain the benign behavior of these abundant adenomas.

\section{RESULTS AND DISCUSSION}

\section{Assessment of senescence biomarkers in pituitary tumor cell lines and characterization of $\mathrm{MtT} / \mathrm{S}$ cells senescent phenotype}

We first explored whether a pituitary tumor cell line could serve as a suitable model for studies of senescence in pituitary tumors. For this, we analyzed the senescent markers, senescence-associated beta-galactosidase
(SA- $\beta$-gal) and $\mathrm{pRb} / \mathrm{p} 16^{\mathrm{INK} 4 \mathrm{a}}$ in several pituitary tumor cell lines (MtT/S, $\alpha \mathrm{T} 3-1$, AtT-20, GH3 and GH4), and found that $\mathrm{MtT} / \mathrm{S}$ cells present a clear senescent phenotype. These cells have increased SA- $\beta$-gal activity (Figure 1A) and $\mathrm{p} 16^{\mathrm{INK} 4 \mathrm{a}}$ expression (Figure $1 \mathrm{~B}$ ) and, consequently, decreased $\mathrm{pRb}$ expression (Figure 1B). Previous research performed on the $\mathrm{MtT} / \mathrm{S}$ cell line showed that it cannot develop tumors unless exogenous IL-6 is present [34]. In contrast, it was also shown that the injection of the other cell lines, that do not have a senescent phenotype, i.e. AtT20 [35], $\alpha \mathrm{T} 3-1$ [36], GH3 [22] and GH4 [37], develop tumors in nude mice. These findings indicate that the somatotrophic MtT/S cell line presents senescent features. The study of senescence in vitro makes use of cell lines which reached, or are near to reach $[38,39]$, their Hayflick limit or that were manipulated to develop the phenotype $[32,38,40]$. It has been observed that the mouse pituitary gonadotroph cell line L $\beta$ T2 presents some senescent features which were increased by the overexpression of PTTG [41]. Our findings show that the rat somatotroph cell line $\mathrm{MtT} / \mathrm{S}$ presents a senescent phenotype, and constitutes an interesting model of pituitary tumor senescence.

Based on the described role of IL-6 in OIS [32], we analyzed whether these cells produce IL-6 and its role in growth versus senescent phenotype. MtT/S cells increase IL-6 production 10-35\% after LPS stimulation (Figure 1C). LPS treatment with concentrations that increased IL-6 production did not affect MtT/S cell proliferation (Figure 1D), showing that endogenous production of IL-6 does not affect proliferation. On the contrary, stimulation with exogenous IL-6 increased $\mathrm{MtT} / \mathrm{S}$ cell proliferation (Figure 1E). IL-6 exerts the maximum effect at $1 \mathrm{ng} / \mathrm{ml}$, higher doses do not have a greater effect, but still induce proliferation, probably because of saturating the receptors. Incubation of $\mathrm{MtT} / \mathrm{S}$ cells with LPS concentrations that increased their IL-6 production, and do not affect its proliferation, led to an increase in SA- $\beta$-gal activity (Figure $1 F$ ). Incubation with exogenous IL-6, on the other hand, did not affect SA- $\beta$ gal activity (Figure 1G). Interestingly, even adding IL-6 at similar concentrations to those produced by MtT/S under LPS stimulation have not effect on SA- $\beta$-gal, showing that the source of IL- 6 is critical for its action.

In order to verify that the endogenous IL-6 directly regulates SA- $\beta$-gal activity, we silenced IL- 6 in MtT/S cells with a siRNA directed specifically towards rat IL-6 (Supplementary Figure 1A). Transfection with this siRNA resulted in decreased in SA- $\beta$-gal activity (Figure $1 \mathrm{H}$ ).

\section{Generation of MtT/S shIL-6 clones and role of IL-6 in pituitary MtT/S senescence in vivo}

To further characterize the role of IL-6, we generated clones of MtT/S by stable transfection with plasmids coding simultaneously for shRNA targeting rat IL-6 and 
A
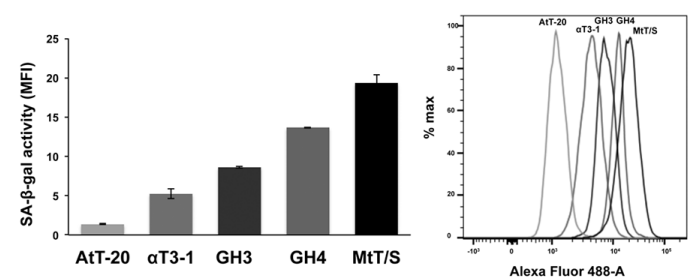

C

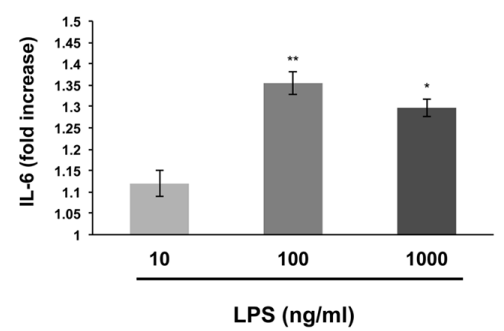

D

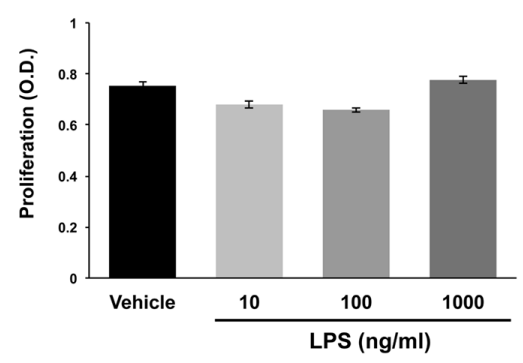

$\mathbf{F}$

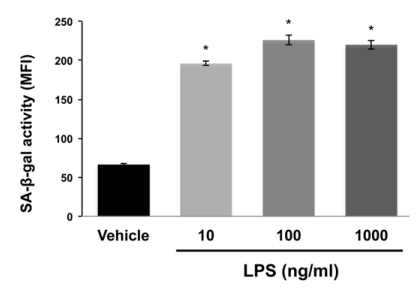

H

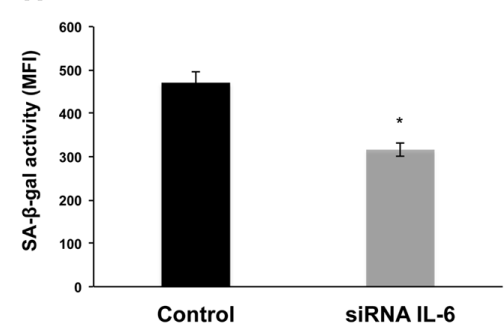

B

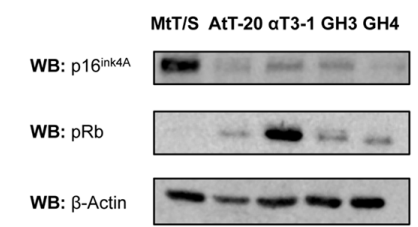

E

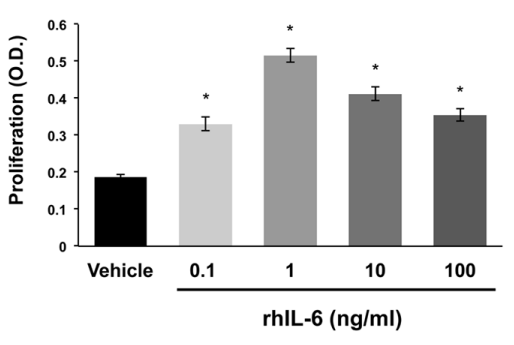

$\mathbf{G}$

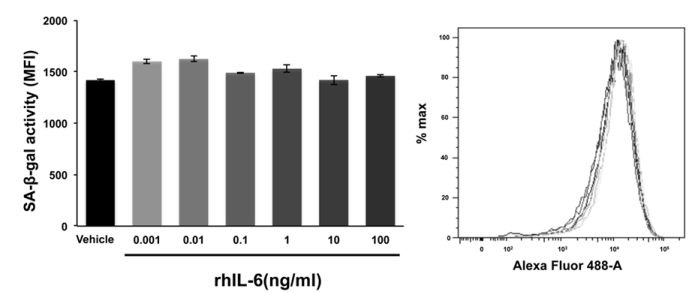

Figure 1: MtT/S pituitary cell line presents a senescent phenotype modulated by endogenous IL-6. A. SA- $\beta$-gal activity was measured by flow cytometry. The bar graph represents the SA- $\beta$-gal activity measured by the mean fluorescence intensity (MFI). B. To assay $\mathrm{pRb}$ and $\mathrm{p} 16^{\mathrm{INK} 4 \mathrm{a}}$ protein levels, cell extracts were subjected to western blot (WB) with the indicated antibodies. $\beta$-Actin was used as loading control. C. IL-6 secretion by MtT/S cells under basal and stimulated conditions with LPS was measured by ELISA. Values represent the average fold stimulation with respect to basal. Absolute values of basal (similar to vehicle) IL-6: $72.71 \pm 0.74 \mathrm{pg} / \mathrm{ml}$ (30,000 cells/well). D-E. Effect of LPS and rhIL-6 on MtT/S cell proliferation, measured with the WST-1 assay $\left(\mathrm{A}_{450 \mathrm{~nm}}\right)$. F-H. Effect of LPS, rhIL-6 and siRNA IL-6 on MtT/S SA- $\beta$-gal activity. The grey scale used in the histogram plot correspond to the grey scale used in the bar graph, which represent the SA- $\beta$-gal activity measured by the mean fluorescence intensity (MFI). One representative experiment from three independent experiments $(\mathrm{N}=4$ for each condition in each experiment) with similar results is shown. Results are expressed as mean \pm SEM. ${ }^{*} p<0.05$ and ${ }^{*} p<<0.01$ compared with cells treated with vehicle $(\mathrm{C}-\mathrm{G})$ or cells transfected with siRNA GL3 as control (H). ANOVA with Scheffé's test. 
eGFP. The insertion of the plasmid and the IL- 6 silencing was verified by confocal microscopy and by measuring mRNA levels and protein secretion (Supplementary Figures 1B, 1C and 1D), and STAT3 phosphorylation was measured to confirm that IL-6 silencing was sufficient to affect its biological function (Supplementary Figure 1E). GH expression shows a reduction in MtT/S shIL-6 clones (Supplementary Figure 1F), which is in accordance with the known stimulatory action of IL-6 on GH [30, 33] and the recently described stimulation of STAT3 on GH [42]. All the experiments were performed in three independent clones (for both shRNA IL-6 and unspecific shRNA) and similar results were obtained.

In these clones we first analyzed SA- $\beta$-gal and, in line with our previous results, we observed that IL-6 silenced clones present decreased SA- $\beta$-gal activity (Figure 2A). Further we studied the expression of the cell cycle regulators $\mathrm{p} 16^{\mathrm{INK} 4 \mathrm{a}}$ and $\mathrm{pRb}$, observing decreased p16 $6^{\mathrm{INK} 4 \mathrm{a}}$ but increased expression of $\mathrm{pRb}$ compared to wild type and control-scramble plasmid transfected cells (MtT/S scr) (Figure 2B). Stable silencing of IL-6 produced a significant increase in proliferation (Figure 2C) and invasive capacity of MtT/S cells (Figure 2D). There are different IL-6 signaling pathways described [43, 44] that can account for the autocrine and paracrine differential signaling all of which involve STAT3 activation, but also integrate different cross-talk pathways that may explain the differential action on proliferation and senescence. An important role for gp130/STAT3 has been shown in corticotroph cells $[45,46]$, and might be involved on the IL-6 action observed in these cells.

In order to prove that endogenous IL-6 induces senescence and avoids the development of $\mathrm{MtT} / \mathrm{S}$ cells into tumors, we injected the MtT/S shIL-6 clones into nude mice. As described for the $\mathrm{MtT} / \mathrm{S}$ wild type cells [34], MtT/S scr did not form tumors (Figure 2E). However, mice injected with the IL-6 silenced clones developed tumors that started to be observable at 35-45 days after being injected (Figure 2E). This result indicates that these clones, that escape senescence in vitro, are able to enter tumorigenesis in vivo.

$\mathrm{MtT} / \mathrm{S}$ wild type cells co-injected with $\mathrm{TtT} / \mathrm{GF}$ cells, due to the production of IL-6 by these cells, are able to develop tumors $[34,47]$. In order to analyze the impact of the IL-6 silencing on the senescence biomarkers in vivo, and taking into account that $\mathrm{MtT} / \mathrm{S}$ wild type or scramble do not establish tumors, we compared the senescent markers of the tumors developed by the coinjection of MtT/S scr with IL-6 producing TtT/GF cells and those produced by the cells in which endogenous IL-6 is silenced, that show similar sizes and weights (Figure 2F). We observed that tumors developed by MtT/S shIL-6 clones present a lower SA-b-gal activity (Figure 2G), lower expression of p16 $6^{\mathrm{INK} 4 \mathrm{a}}$ (Figure 2H) and higher expression of $\mathrm{pRb}$ (Figure 2I) than the ones generated by the co-injection of MtT/S scr and TtT/GF.

The facts that MtT/S cells do not generate tumors and that the absence of endogenous IL- 6 allowed them to bypass
A

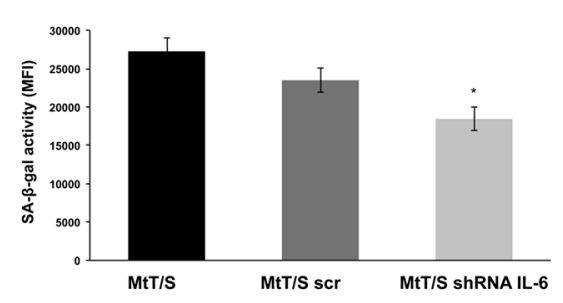

C

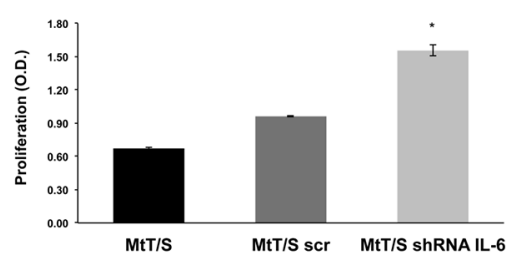

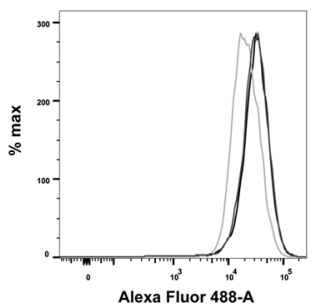

B

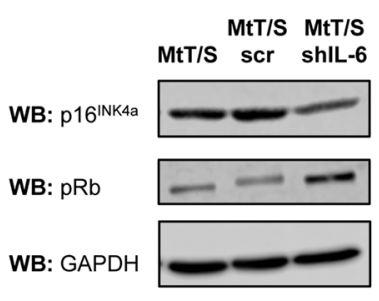

D

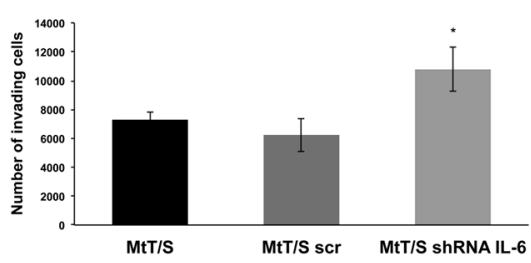

Figure 2: IL-6 silenced clones present decreased senescent biomarkers and acquire the capacity to form tumors. A. SA- $\beta$-gal activity was measured on MtT/S wild type (MtT/S), MtT/S control (MtT/S scr) and MtT/S IL-6 silenced (MtT/S shIL-6) clones, by flow cytometry. The bar graph represents the SA- $\beta$-gal activity measured by the mean fluorescence intensity (MFI). B. For pRb and $\mathrm{p} 16^{\mathrm{INK} 4 \mathrm{a}}$ protein levels, cell extracts were subjected to western blot (WB) with the indicated antibodies. GAPDH was used as loading control. C-D. Cell proliferation, measured by WST-1 assay $\left(\mathrm{A}_{450 \mathrm{~nm}}\right)$, and cell invasion, measured using transwells, were performed on $\mathrm{MtT} / \mathrm{S}, \mathrm{MtT} / \mathrm{S}$ scr and MtT/S shIL-6 clones. One representative experiment from three independent experiments $(\mathrm{N}=3$ for each condition in each experiment) with similar results is shown (A-D). Results are expressed as mean $\pm \mathrm{SEM}$. * $\mathrm{p}<0.05$ compared with MtT/S and MtT/S scr, ANOVA with Scheffé's test (A, C and D). (Continued) 
$\mathbf{E}$

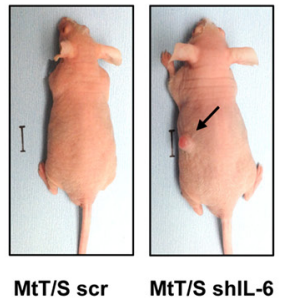

G
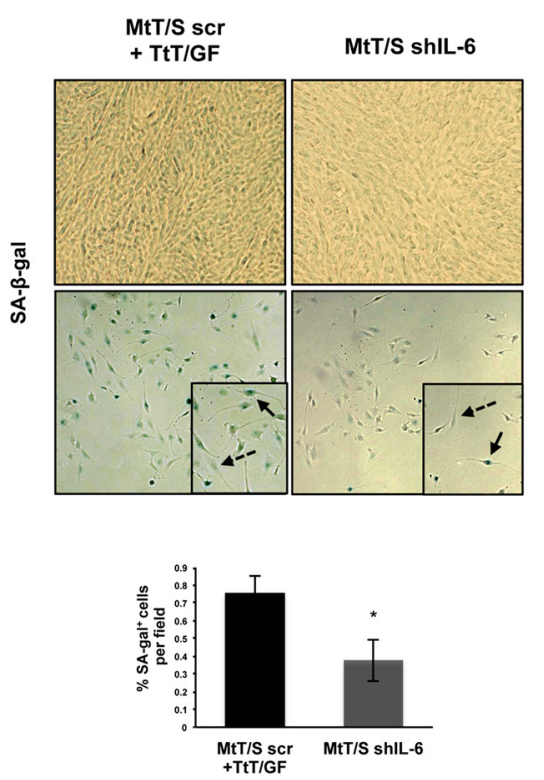

$\mathbf{F}$

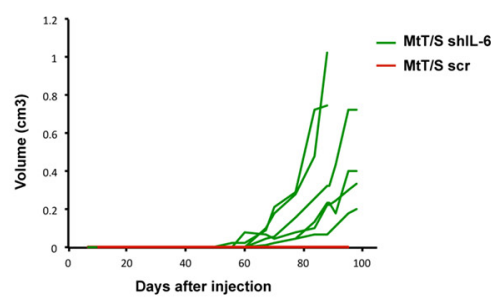

H

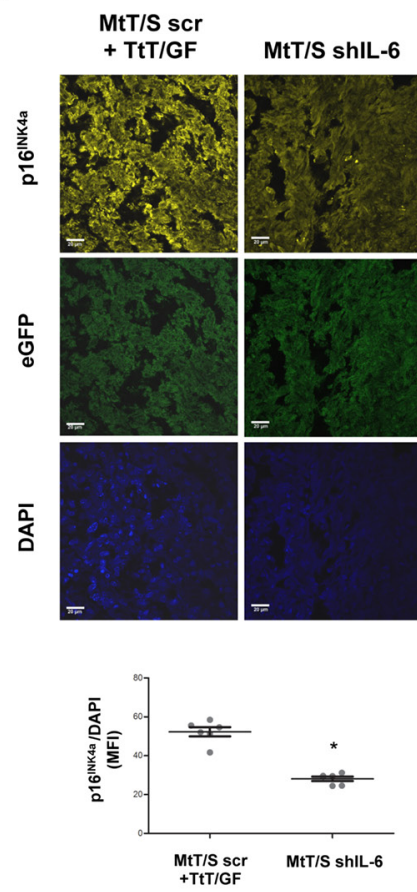

I
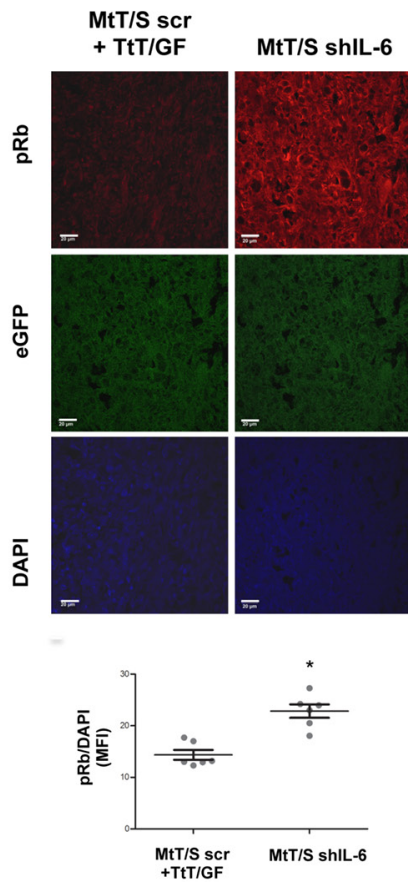

Figure 2: (Continued) IL-6 silenced clones present decreased senescent biomarkers and acquire the capacity to form tumors. E. MtT/S scr and MtT/S shIL-6 clones were injected subcutaneously $\left(5 \times 10^{5}\right.$ cells for each clone). Photographs were taken at 70 days. One mouse with similar results to all the others of each group is shown (i.e. no tumor in all the animals injected with MtT/S scr cells and tumors similar to the one shown in the picture in all animals injected with MtT/S shIL-6). Volume of each of the tumors of one of three independent experiments with six mice in each group in each experiment with similar results is shown. The six MtT/S scr mice did not form tumors and overlap in one red line and the volume from each of the tumors from the MtT/S shIL-6 group is shown in green. F. MtT/S scr with TtT/GF and MtT/S shIL-6 cells were injected subcutaneously in 2 groups of five male nude mice $\left(5 \times 10^{5}\right.$ cells for each clone and $1,8 \times 10^{5} \mathrm{cell}$ for TtT/GF). Photographs of mice were taken at 70 days. Tumor weights were obtained at the end of the experiment. One mouse and one tumor with similar results to the others of each group are shown. Three independent experiments with five mice in each group in each experiment were performed, showing similar results. Weights of one of these experiments are shown in the graph. G. $6 \mu \mathrm{m}$ tumor cryosections (upper panel, $\mathrm{x} 20$ magnification) and primary cell cultures derived from the same tumor (lower panel, $\mathrm{x} 10$ magnification) were stained for SA- $\beta$-gal. Arrows and dotted line arrows indicate examples of SA- $\beta$-gal positive and negative cells, respectively. Quantification of positive SA- $\beta$-gal cells is shown. Results obtained from 20 independent pictures for each condition are expressed as mean \pm SEM. H-I. $6 \mu \mathrm{m}$ tumor sections were stained by double immunofluorescence with $\mathrm{p} 16^{\mathrm{INK} 4 \mathrm{a}}$ (yellow; 1:50), pRb (red; 1:50) and 4',6-diamidino-2phenylindole (DAPI) for staining cell nuclei (blue). Tumors developed by the injected cells were verified by the detection of eGFP (green). Images were acquired at $x 63$ magnification (scale bar: $20 \mu \mathrm{m}$ ). $\mathrm{p} 16^{\mathrm{INK} 4 \mathrm{a}}$ and $\mathrm{pRb}$ were quantified by the mean fluorescence intensity (MFI) and relativized to DAPI signal. Results obtained from six independent pictures for each condition are expressed as mean \pm SEM. One representative picture for each condition is shown. ${ }^{*} \mathrm{p}<0.05$ compared with tumors developed by the co-injection of MtT/S scr and TtT/GF, Student $t$ test (H-I).

senescence and consequently develop into tumors, support the idea that IL-6 by its autocrine action contribute to maintain the senescent phenotype of these tumoral cells. To determine
IL-6 autocrine action in vivo, we compared senescent markers in tumors expressing (MtT/S scr cells co-injected with TtT/GF cells) or lacking (MtT/S shIL-6) endogenous 
A

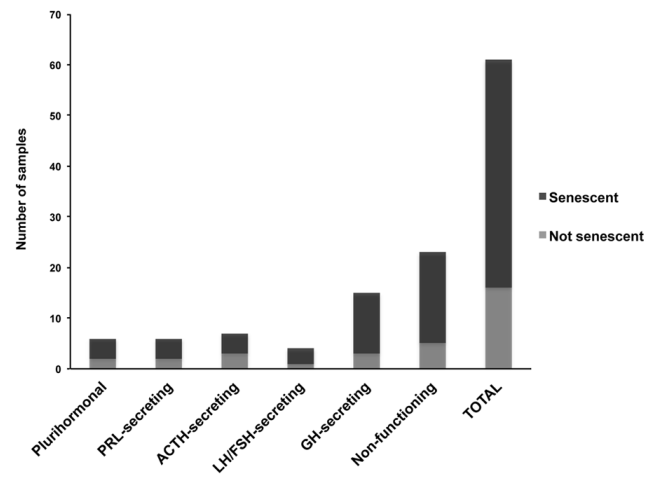

C

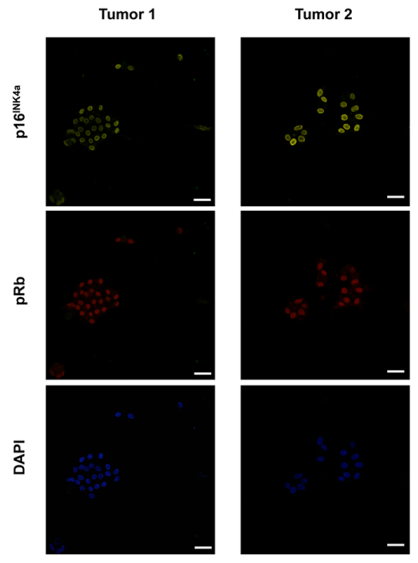

E

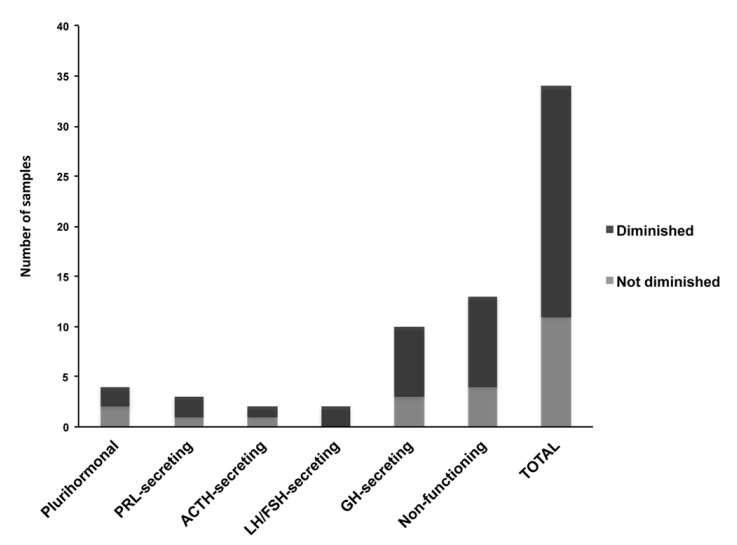

B

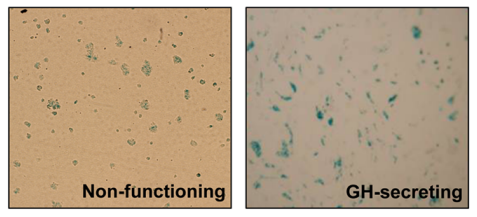

D
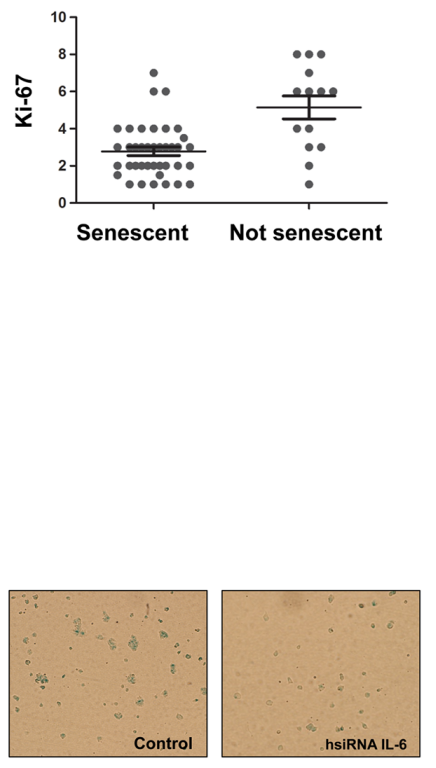

G

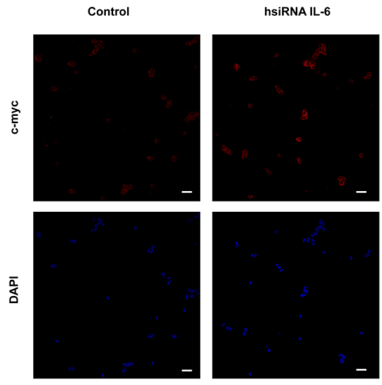

Figure 3: Human pituitary tumor samples express SA-b-gal modulated by IL-6. A. Primary human pituitary cell cultures prepared from 61 samples of human pituitary tumor samples were stained for SA- $\beta$-gal (6 plurihormonal, 6 PRL-secreting, 7 ACTHsecreting, $4 \mathrm{LH} / \mathrm{FSH}$-secreting, $15 \mathrm{GH}$-secreting and 23 non-functioning tumors). Black zone of the bars represents positive samples, while grey zone represents negative samples. B. Photographs of positive SA- $\beta$-gal staining from a non-functioning and a GH-secreting tumor are shown. C. Photographs of positive $\mathrm{p} 16^{\mathrm{INK} 4 \mathrm{a}}$ (yellow; 1:50) and $\mathrm{pRb}$ (red, 1:50) staining from a non-functioning and a GHsecreting tumor are shown. 4',6-diamidino-2-phenylindole (DAPI) were used for staining cell nuclei (blue). Images were acquired at x63 magnification (scale bar: $20 \mu \mathrm{m}$ ). D. By Pearson correlation analysis it was determined that senescence correlates negatively with the cellular marker of proliferation Ki-67 in human pituitary adenomas (Pearson coefficient $=-0.3245, \mathrm{p}<0.05$ ). E. Positive samples of human pituitary tumors $(\mathrm{N}=34)$ were electroporeted with $10 \mathrm{mM}$ hsiRNA IL-6 or $10 \mathrm{mM}$ siRNA GL3 and then stained for SA- $\beta$-gal. Black zone of the bars represents samples in which SA- $\beta$-gal staining were significantly diminished (Student $t$ test, $p<0.05$ ), while grey zone represents samples in which SA- $\beta$-gal staining did not vary. F. Photographs of a representative non-functioning tumor with significant decrease in SA$\beta$-gal with hsiRNA IL-6 are shown. Images were acquired at x40 magnification. G. Photographs of a representative non-functioning tumor with significant increase in c-myc (red, 1:50) with hsiRNA IL-6 are shown. 4',6-diamidino-2-phenylindole (DAPI) were used for staining cell nuclei (blue). Images were acquired at x40 magnification (scale bar: $20 \mu \mathrm{m}$ ). 
IL-6. Thus we were able to compare the tumor developed by the silencing of IL-6 (i.e. the abolishment of senescence) with a tumor resembling the natural situation in which both the paracrine proliferative IL- 6 and the autocrine-inducing senescence are on. In support of the notion about the role of IL-6, the tumors expressing endogenous IL-6 present a more pronounced senescent phenotype.

\section{Role of IL-6 in senescence of human pituitary adenomas}

To characterize the senescent phenotype of the human pituitary adenomas, and confirming previous reports of senescence in pituitary tumors [18, 19], SA$\beta$-gal staining was performed on primary cell cultures prepared from 61 adenoma tissue samples. 74\% (45/61) of the analyzed samples were positive for the SA- $\beta$-gal staining (Figure $3 \mathrm{~A}$ and $3 \mathrm{~B}$ ). In 6 of these positive samples we further analyzed $\mathrm{p} 16^{\mathrm{INK} 4 \mathrm{a}}$ and $\mathrm{pRb}$ and they all express these other senescence markers (Figure 3C). We found a negative correlation between senescence and the cellular marker of proliferation Ki-67 (Figure 3D), suggesting that, as hypothesized, senescence prevents proliferation of pituitary tumors. The higher incidence of senescence was found in GH-secreting (12/15) and non-functioning (NF) tumors (18/23), as previously observed [19]. Of note, none of the GH senescent adenomas and only $10 \%$ of the total senescent tumors were invasive.

Primary cell cultures derived from positive SA- $\beta$-gal staining tumor samples (Figure 3A) were electroporated with siRNA targeting human IL-6 (hsiRNA IL-6) or unspecific siRNA as control. The levels of IL-6 in the tumors after silencing were verified with a fluorescentcoupled oligonucleotide and by immunofluorescence with a specific antibody against IL-6 (Supplementary Figures $2 \mathrm{~A}$ and 2B). As shown in Figure 3E and 3F, 68\% (23/34) presented a significant reduction in the SA- $\beta$-gal staining when endogenous IL-6 was decreased. The IL- 6 siRNA also produced an increase in the expression of c-myc (Figure 3G).

We describe here that IL-6, beside its previously known action on proliferation and regulation of $\mathrm{GH}$ (as observed in the MtT/S shIL-6 clones), plays a fundamental role in senescence in pituitary tumors, contributing to explain their benign characteristics. Regardless of the abundance of pituitary adenomas [48], they are not commonly metastatic [49-52]. The protective role of OIS may provide an interesting mechanism to further understand this behavior. OIS demands time to develop, enabling an initial proliferative phase, that results in a benign tumor with stable growth arrest, which is the natural history of most of pituitary adenomas. Initial studies described senescence and PTTG involvement in human pituitary adenomas [18, 19], although the mechanisms underlying this behavior remain an open question. Different to most human GH-producing pituitary adenomas in which PTTG overexpression is associated with p21-dependent senescence [19], tumors arising from the gonadotroph lineage also exhibit high PTTG levels, but p21 is not expressed in gonadotroph-derived non-functioning pituitary adenomas, which express $\mathrm{p} 15^{\mathrm{INK} 4 \mathrm{~b}}$ and $\mathrm{p} 16^{\mathrm{INK} 4 \mathrm{a}}$, pointing to a differential lineage-specific pathways restricting and controlling pituitary cell cycle progression [41]. Epigenetic changes, such as demethylation of specific genes [53], that may also occur on cytokines [54], or cell cycle regulators [55, 56], might also be involved in the cascade of events leading to the senescence phenotype of pituitary tumors. Given its role both in pituitary pathophysiology [24, 30, 33, 57, 58] and in OIS [32], we focused on IL-6 as a potential candidate for mediating this processes during pituitary adenoma development.

The pituitary has a considerable degree of plasticity and self-renewal capacity. Recent progress described the characterization of adult pituitary stem cells (SCs) [5962]. Several cell types and populations, including FS cells, have been considered to represent SCs [63-65]. Current data suggests that SCs have a tumorigenic potential. The initial mutation that drives pituitary tumorigenesis may occur in SCs and through the secretion of mitogenic signals (interleukins, chemokines and growth factors) induce the transformation of surrounding cells that will form a tumor [66]. Paracrine IL-6 is one of the factors that these cell types, which do not form part of the tumor, may secrete.

In the normal pituitary paracrine IL-6 delivered by FS cells may act to induce the development of an adenoma, by promoting tumor cell expansion (Figure 4). In line

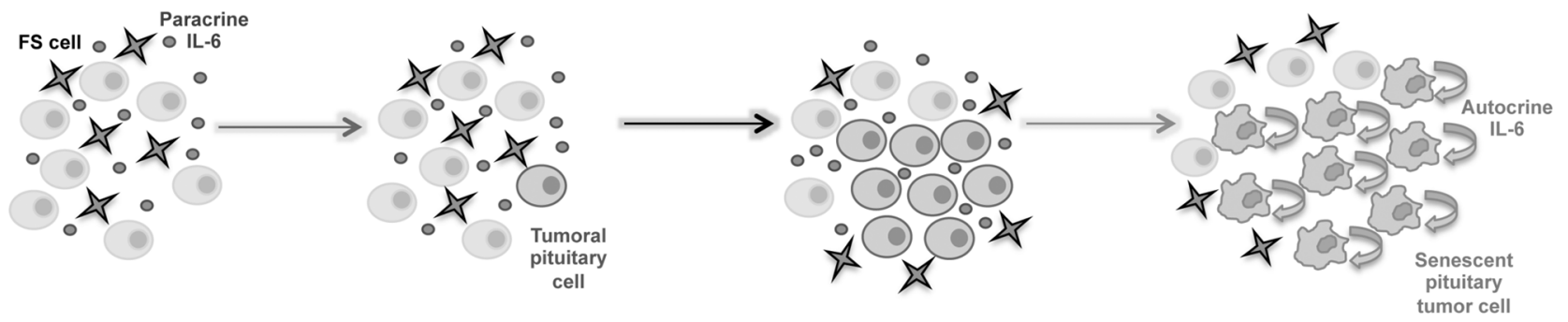

Figure 4: Pituitary senescence progression model. Pituitary tumor pathogenesis has an initial proliferative phase involving IL-6 secreted from the FS cells, which induces proliferation of the pituitary tumor cells. It is followed by a phase of stopping proliferation in which senescence mediated by the autocrine IL-6 produced by the tumor cells themselves, might contribute to establish a benign tumor with stable growth arrest. 
with this, previous works have proven that the $\mathrm{MtT} / \mathrm{S}$ cell line depends on the folliculostellate $\mathrm{TtT} / \mathrm{GF}$ cell line to produce tumors in nude mice [34, 47]. IL-6 secreted by the FS that surround the tumoral cells may also induce extracellular matrix remodeling and vessel formation [25]. After mutation of a normal pituitary cell, autocrine IL-6 in the same tumor may trigger senescence and contribute in this way to control aggressive growth and malignant development of these cells (Figure 4). Several signaling mechanisms for IL-6 have been described, involving a soluble form of the receptor and an endocytosis mechanism [43, 44]. Endogenous IL-6 may involve one of those, or another still unknown pathway, that is not activated by the membrane receptor, e.g. exogenous IL-6. Future research will clarify the interesting open question about the mechanisms involved in the differential action.

Senescence in the pituitary constitutes a mechanism that may contribute not only to restrain proliferation but to allow the pituitary cells to remain viable and accomplish its physiological function, which supports the vital functioning of the pituitary gland for its involvement in the homeostasis control.

Evidence supporting OIS as a physiologically relevant mechanism stopping tumor formation as well as linking to the induction of an inflammatory transcriptome, is rapidly emerging. Our findings demonstrate for the first time the involvement of IL-6 in a natural tumor model.

\section{MATERIALS AND METHODS}

\section{Materials}

Unless otherwise stated, reagents were obtained from Life Technologies or Sigma Chemical Co.

\section{Cell culture and stimulation}

Cell lines AtT-20, GH3 and GH4 acquired from ATCC, either directly or by colleagues, MtT/S and TtT/ $\mathrm{GF}$ directly obtained from $\mathrm{K}$. Inoue who generated the cells as described below [67, 68], and aT3-1 provided by P. Mellon who generated them [69], were kept frozen immediately after receipt and used each cycle in culture for less than 4 months. ATCC cell lines are characterized by Short Tandem Repeat (STR) profiling. MtT/S cells, a rat somatotrophic pituitary cell line obtained from an estrogen-induced somatotrophic tumor [67], and TtT/ $\mathrm{GF}$, a murine folliculostellate cell line obtained from a thyrotrophic pituitary tumor [68], were cultured as described [34]. MtT/S clones, generated as indicated below, were cultured under the same conditions as $\mathrm{MtT} / \mathrm{S}$ cells but adding Puromycin to the medium. AtT20, a mouse corticotroph cell line, GH3 and GH4, rat lactosomatotroph cell lines, and $\alpha \mathrm{T} 3-1$, a mouse pituitary gonadotroph cell line, were culture as described [23, 69].

Primary human pituitary adenomas and $\mathrm{MtT} / \mathrm{S}$ shIL-6 or MtT/S scr and TtT/GF tumor cell cultures were performed as described [31, 34]. Briefly, the tissue was washed several times with preparation buffer (137 $\mathrm{mmol} / \mathrm{L} \mathrm{NaCI}, 5 \mathrm{mmol} / \mathrm{L} \mathrm{KCl}, 0.7 \mathrm{~mol} / \mathrm{L} \mathrm{Na}_{2} \mathrm{HPO}_{4}, 10$ mmol/L glucose, $15 \mathrm{mmol} / \mathrm{L}$ HEPES, $\mathrm{pH} 7.3,2.5 \mathrm{mg} / \mathrm{L}$ amphotericin B, and $10^{5} \mathrm{U} / \mathrm{L}$ penicillin/streptomycin). Sliced fragments were mechanically and enzymatically dispersed in preparation buffer containing $1000 \mathrm{U} /$ $\mathrm{mL}$ collagenase, $4 \mathrm{~g} / \mathrm{L}$ BSA, $10 \mathrm{mg} / \mathrm{L}$ DNAse II, $1 \mathrm{~g} / \mathrm{L}$ soybean trypsin inhibitor, and $2 \mathrm{~g} / \mathrm{L}$ hyaluronidase. Cells were centrifuged and resuspended in Dulbecco's modified Eagle's medium ( $\mathrm{pH} 7.3$ ) containing 10\% fetal bovine serum, $2.2 \mathrm{~g} / \mathrm{L} \mathrm{NaHCO}_{3}, 10 \mathrm{mmol} / \mathrm{L}$ HEPES, 2 $\mathrm{mmol} / \mathrm{L}$ glutamine, $10 \mathrm{~mL} / \mathrm{L}$ nonessential amino acids, $10 \mathrm{~mL} / \mathrm{L}$ minimal essential medium vitamins, $2.5 \mathrm{mg} / \mathrm{L}$ amphotericin $\mathrm{B}$, and $10^{5} \mathrm{U} / \mathrm{L}$ penicillin/streptomycin, 5 $\mathrm{mg} / \mathrm{L}$ insulin, $20 \mathrm{mg} / \mathrm{L}$ sodium selenite and $30 \mathrm{pmol} / \mathrm{L} \mathrm{T}_{3}$. Isolated $2 \times 10^{5}$ stromal adenoma cells, in absence of FS cells as previously described [70], with a viability of at least $80 \%$ (acridine orange/ethidium bromide staining) were cultured under a 5\% $\mathrm{CO}_{2}$ atmosphere at $37 \mathrm{C}$.

For LPS and rhIL-6 (R\&D Systems, Minneapolis, Minnesota, USA) stimuli, cells were cultured in 2\% FBS DMEM for $16 \mathrm{~h}$ before stimulation. Cells were treated with indicated doses of LPS or rhIL-6 for $24 \mathrm{~h}$ or $72 \mathrm{~h}$, according to the experiment performed. The same diluent (vehicle) was used as control in all experiments.

\section{Transfections}

MtT/S cells transfection with siRNA against rat IL-6 (5'-GAUGGUUUCUUGCAAUAUATT-3') or unspecific siRNA (5'-CUUACGCUGAGUACUUCGATT-3') were performed using Lipofectamine 2000 reagent following the manufacturer's instructions.

Stable clones were obtained as described [22]. $\mathrm{MtT} / \mathrm{S}$ cells were transfected with each shRNA plasmids directed against rat IL-6 from (Kit Hush ${ }^{\circledR}$ shRNA, OriGene, Rockville, Maryland, USA) or an unspecific shRNA (5'-GCACTACCAGAGCTAACTCAGATAGT ACT-3'). Plasmids also encode for the green fluorescent protein (GFP). For each shRNA, depending on their proliferative capacity and suitable morphology, 5 clones were selected and amplified. Clones were selected and maintained with $1 \mu \mathrm{g} / \mathrm{ml}$ Puromycin (Invivogen, San Diego, California, USA). Endogenous IL-6 expression levels were checked by RT-PCR, ELISA, and also by checking the expression of eGFP using confocal microscopy. Initial studies showed that all clones had similar results. All experiments were performed in three clones, and results from clone 36 are shown.

Primary human pituitary adenoma cultures were transfected [71], with 100mM siRNA against human IL-6 (5'-CCCAGGAGAAGAUUCCAAATT-3') or unspecific siRNA, or with BLOCK-it. After electroporation (using a GenePulser from Bio-Rad, Hercules, California, USA) cells were platted, $72 \mathrm{~h}$ after, SA- $\beta$-staining was performed. 


\section{Reverse transcription-PCR}

RT-PCR was performed as previously described [22]. PCR was performed with the specific primers: GAPDH upper primer: 5'-AAGGCTGTGGGCAAGGTCATC-3, GAPDH lower primer: 5'-CGAAGGTGGAAGAGTGGGAGTTG-3'; $\beta$-actin upper primer: 5'-GTGGGCCGCTCTAGGCACCA-3'; $\beta$-actin lower primer: 5'-CGGTTGGCCTTAGGGTTCAGG GGGG-3'; rat IL-6 upper primer: 5'-ATCTGCTCTGGTCTT CTGG-3', rat IL-6 lower primer: 5'-GATGAGTTGGATGGT CTTG-3.

\section{IL-6 secretion}

$\mathrm{MtT} / \mathrm{S}$ and MtT/S clone cells were plated at $80 \%$ confluence. $24 \mathrm{~h}$ later medium were collected and stocked at $-80 \mathrm{C}$ until IL-6 determination, as described [70]. A rat IL-6 ELISA Kit (R\&D Systems) was used.

\section{Western blot}

Cell lysates were prepared in standard cracking buffer and boiled for $5 \mathrm{~min}$ at $95 \mathrm{C}$. Cell extracts were subjected to SDS-polyacrilamyde gel electrophoresis (SDS-PAGE) as previously described [22]. Proteins were blotted onto nitrocellulose membranes using standard procedures, and incubated with $\mathrm{p} 16^{\mathrm{INK} 4 \mathrm{a}}(1: 1000)$, STAT3 (1:1000), phosphoSTAT3 (1:1000), $\beta$-Actin (1:3000) (Santa Cruz Biotechnologies, California, USA), pRb (1:1000, Cell Signalling Technology, Danvers, Massachusetts, USA), GH (1:1000) or GAPDH (1:10000) (Abcam, Cambridge, Massachusetts, USA) antibodies overnight, followed by corresponding secondary antibodies incubation.

\section{Cell proliferation}

$1 \times 10^{3}$ cells were platted and $72 \mathrm{~h}$ later a WST1 assay Roche Molecular Biochemicals, Mannheim, Germany) was used to measure viability and proliferation following the manufacturer's instructions. The reactions product was measured in an ELISA plate reader at $450 \mathrm{~nm}$, as previously described [23].

\section{Cell invasion}

Invasion assay was performed in $6.5 \mu \mathrm{m}$ Transwells (Corning, New York, USA), that were first coated with Matrigel Matrix (Corning). Cells (5x104) suspended in 100 $\mathrm{ml}$ serum-free medium were added to the upper chamber and the lower chamber was filled with DMEM medium with $10 \%$ FBS. Cells were allowed to invade at $37 \mathrm{C}$ for $24 \mathrm{~h}$. After removing non-invading cells, membranes were fixed in methanol and stained with 4',6-diamidino2-phenylindole (DAPI). Images of invading cells were captured by a LSM 710 AxioObserver fluorescence microscope (Carl-Zeiss, Jena, Germany), acquired with ZEN 2011 software (Carl-Zeiss) and counted with ImageJ.

\section{In vivo experiments in nude mice}

$\mathrm{MtT} / \mathrm{S}$ derived clones (MtT/S scr and MtT/S shIL6) and TtT/GF were harvest by trypsinization, washed twice with PBS, resuspended in DMEM, and injected subcutaneously, as described [22, 34], into the flanks of 6- to 8-week-old male nude mice (strain N:NIH (S)-FoxnInu), obtained from Fundación Facultad de Ciencias Veterinarios, National University of La Plata, Argentina. Two independent groups of six mice were injected with $5 \times 10^{5}$ cells of MtT/S scr or MtT/S shIL-6, and two independent groups of five mice were injected with $5 \times 10^{5}$ cells for each clone and $1.8 \times 10^{5}$ cell for $\mathrm{TtT} /$ GF. Animals were examined for tumor formation every 3 days and tumor growth was determined as described $[22,34]$. All experimental protocols were approved by the Ethical Committee on Animal Care and Use (CICUAL), University of Buenos Aires, Argentina.

Nude mice tumors explants were frozen or embedded into paraffin blocks. To prepare cryosections the Microm HM 550 cryostat (Thermo Scientific, Waltham, Massachusetts, USA) was used and to prepare sections of paraffin-embedded, the RM2235 rotary microtome (Leica, Wetzlar, Germany).

\section{Tumors}

Human pituitary adenoma tissues were obtained from the Neurosurgery service, Hospital Italiano, Argentina and Neurosurgery department, FLENI, Argentina. This study complies with the June 1964 Declaration of Helsinki, has been approved by the hospital ethics committee, and informed written consent was received from each patient whose tumor tissue was used in the study.

A portion of the tumor tissue, after transsphenoidal surgery, was received in sterile medium. 61 pituitary adenomas were diagnosed according to clinical, biochemical, radiological and surgical findings as well as by routine immunohistochemistry and were classified as somatotrophinomas $(\mathrm{n}=15)$, corticotrophinomas $(\mathrm{n}=7)$, prolactinomas $(\mathrm{n}=6)$, tyrotrophinomas $(\mathrm{n}=4)$, plurihormonal adenomas $(\mathrm{n}=6)$ and non-functioning adenomas $(n=23)$, and cultured as described in the cell culture section. All human tumor samples with clinical and immuno-histochemical confirmed diagnosis made at the Hospitals, that have been sent by the neurosurgeons during the time of this study, were included in the first SA- $\beta$-gal analysis of this study, no samples obtained were discarded. All positive SA- $\beta$-gal samples were electroporated with IL-6 siRNA as described above and further cultured; 34 of these that were able to establish a viable primary culture, were further analyzed. 


\section{SA- $\beta$-gal activity}

Hystochemical and fluorescence detection of SA- $\beta$ gal enzymatic activity were performed as described [72]. Only senescent cells are detected at $\mathrm{pH}$ 6.0.

For hystochemical detection, SA- $\beta$-gal activity was monitored as the percent of cells with SA- $\beta$-gal staining divided by the total number of cells in 20 independent fields. For fluorescence detection using flow cytometry (BD Becton Dockinson FACS CantoII, Heidelberg, Germany), SA- $\beta$-gal activity was measured by the mean fluorescence intensity using $\mathrm{C}_{12} \mathrm{FDG}$ as a substrate that becomes fluorescent after cleavage by the enzyme.

\section{Immunofluorescence}

Six-micrometer sections of paraffin-embedded nude mice tumors, previously fixed with BouinHollande solution, deparaffinized and rehydrated, and primary human pituitary adenoma cultures were incubated $(4 \mathrm{C}, 18 \mathrm{~h})$ with antibodies against $\mathrm{p} 16^{\mathrm{INK} 4 \mathrm{a}}$ (1:50, Santa Cruz Technologies), pRb (1:50, Cell Signalling Technology) or c-myc (1:50, Santa Cruz Technologies). After washing with PBS, samples were incubated (45 $\mathrm{min}$, room temperature) with secondary antibody Alexa Flour 647. Nuclei were stained by DAPI. MtT/S clones were fixed in 4\% PFA and nuclei were stained with DAPI. All samples were mounted with Mowiol mounting medium and observed with a LSM 710 AxioObserver confocal microscope (CarlZeiss). For tumor sections, six independent pictures for each condition were taken. Images were acquired with ZEN 2011 software (Carl-Zeiss) and analyzed in ImageJ.

\section{Statistics and correlation}

Statistics were performed by analysis of variance (ANOVA) in combination with the Scheffe's test or Student $t$ test. Data are shown as mean \pm SEM. Correlations between variables were evaluated by Pearson's correlation. Statistical significance was accepted at $\mathrm{p}<0.05$.

\section{ACKNOWLEDGMENTS AND FUNDING}

We thank Johanna Stalla, Maximiliano Toscano and Sofia A. Beltrame for technical help. This work was supported by grants from the Max Planck Society, Germany (2012); the University of Buenos Aires (20020130100427); the Consejo Nacional de Investigaciones Científicas y Técnicas (D449 (01-032016)); the Agencia Nacional de Promoción Científica y Tecnológica, Argentina (PICT 2012-0431; 2014-3634; 2014-0079) and Fondo para la Convergencia Estructural de Mercosur (COF 03/11).

\section{CONFLICT OF INTEREST}

The authors declare no conflict of interest.

\section{REFERENCES}

1. Collado M, Blasco MA and Serrano M. Cellular senescence in cancer and aging. Cell. 2007; 130:223-233.

2. Campisi J and d'Adda di Fagagna F. Cellular senescence: when bad things happen to good cells. Nat Rev Mol Cell Biol. 2007; 8:729-740.

3. Kuilman T, Michaloglou C, Mooi WJ and Peeper DS. The essence of senescence. Genes Dev. 2010; 24:2463-2479.

4. Baker DJ and Sedivy JM. Probing the depths of cellular senescence. J Cell Biol. 2013; 202:11-13.

5. Young AR, Narita M and Narita M. Cell senescence as both a dynamic and a static phenotype. Methods Mol Biol. 2013; 965:1-13

6. Young AR, Narita M, Ferreira M, Kirschner K, Sadaie M, Darot JF, Tavare S, Arakawa S, Shimizu S, Watt FM and Narita M. Autophagy mediates the mitotic senescence transition. Genes Dev. 2009; 23:798-803.

7. Collado M and Serrano M. The power and the promise of oncogene-induced senescence markers. Nat Rev Cancer. 2006; 6:472-476.

8. Lowe SW, Cepero E and Evan G. Intrinsic tumour suppression. Nature. 2004; 432:307-315.

9. Michaloglou C, Vredeveld LC, Soengas MS, Denoyelle C, Kuilman T, van der Horst CM, Majoor DM, Shay JW, Mooi WJ and Peeper DS. BRAFE600-associated senescencelike cell cycle arrest of human naevi. Nature. 2005; 436:720-724.

10. Goel VK, Ibrahim N, Jiang G, Singhal M, Fee S, Flotte T, Westmoreland S, Haluska FS, Hinds PW and Haluska FG. Melanocytic nevus-like hyperplasia and melanoma in transgenic BRAFV600E mice. Oncogene. 2009; 28:2289-2298.

11. Courtois-Cox S, Genther Williams SM, Reczek EE, Johnson BW, McGillicuddy LT, Johannessen CM, Hollstein PE, MacCollin M and Cichowski K. A negative feedback signaling network underlies oncogene-induced senescence. Cancer Cell. 2006; 10:459-472.

12. Simonetti S, Serrano C, Hernandez-Losa J, Bague S, Orellana R, Valverde C, Lleonart ME, Aizpurua M, Carles J, Ramon y Cajal S and Romagosa C. Schwannomas, benign tumors with a senescent phenotype. Histol Histopathol. 2014; 29:721-730.

13. Melmed S. Pituitary tumors. Endocrinol Metab Clin North Am. 2015; 44:1-9.

14. Melmed S. Pathogenesis of pituitary tumors. Nat Rev Endocrinol. 2011; 7:257-266.

15. Yates CJ, Lines KE and Thakker RV. Molecular genetic advances in pituitary tumor development. Expert Rev Endocrinol Metab. 2015; 10:35-53. 
16. Levy A and Lightman S. Molecular defects in the pathogenesis of pituitary tumours. Front Neuroendocrinol. 2003; 24:94-127.

17. Arzt E, Chesnokova V, Stalla GK and Melmed S. Pituitary adenoma growth: a model for cellular senescence and cytokine action. Cell Cycle. 2009; 8:677-678.

18. Chesnokova V, Zonis S, Rubinek T, Yu R, Ben-Shlomo A, Kovacs K, Wawrowsky K and Melmed S. Senescence mediates pituitary hypoplasia and restrains pituitary tumor growth. Cancer Res. 2007; 67:10564-10572.

19. Chesnokova V, Zonis S, Kovacs K, Ben-Shlomo A, Wawrowsky K, Bannykh S and Melmed S. p21(Cip1) restrains pituitary tumor growth. Proc Natl Acad Sci U S A. 2008; 105:17498-17503.

20. Sapochnik M, Nieto LE, Fuertes M and Arzt E. Molecular Mechanisms Underlying Pituitary Pathogenesis. Biochem Genet. 2016; 54:107-119.

21. Perez-Castro C, Renner U, Haedo MR, Stalla GK and Arzt E. Cellular and molecular specificity of pituitary gland physiology. Physiol Rev. 2012; 92:1-38.

22. Paez-Pereda M, Giacomini D, Refojo D, Nagashima AC, Hopfner U, Grubler Y, Chervin A, Goldberg V, Goya R, Hentges ST, Low MJ, Holsboer F, Stalla GK, et al. Involvement of bone morphogenetic protein 4 (BMP-4) in pituitary prolactinoma pathogenesis through a Smad/ estrogen receptor crosstalk. Proc Natl Acad Sci U S A. 2003; 100:1034-1039.

23. Perez Castro C, Nagashima AC, Pereda MP, Goldberg V, Chervin A, Largen P, Renner U, Stalla GK and Arzt E. The gp130 cytokines interleukin-11 and ciliary neurotropic factor regulate through specific receptors the function and growth of lactosomatotropic and folliculostellate pituitary cell lines. Endocrinology. 2000; 141:1746-1753.

24. Jones TH, Daniels M, James RA, Justice SK, McCorkle R, Price A, Kendall-Taylor P and Weetman AP. Production of bioactive and immunoreactive interleukin-6 (IL-6) and expression of IL-6 messenger ribonucleic acid by human pituitary adenomas. J Clin Endocrinol Metab. 1994; 78:180-187.

25. Renner U, Gloddek J, Pereda MP, Arzt E and Stalla GK. Regulation and role of intrapituitary IL-6 production by folliculostellate cells. Domest Anim Endocrinol. 1998; 15:353-362.

26. Allaerts W and Vankelecom H. History and perspectives of pituitary folliculo-stellate cell research. Eur J Endocrinol. 2005; 153:1-12.

27. Fauquier T, Guerineau NC, McKinney RA, Bauer K and Mollard P. Folliculostellate cell network: a route for longdistance communication in the anterior pituitary. Proc Natl Acad Sci U S A. 2001; 98:8891-8896.

28. Denef C. Paracrinicity: the story of 30 years of cellular pituitary crosstalk. J Neuroendocrinol. 2008; 20:1-70.

29. Ueta Y, Levy A, Chowdrey HS and Lightman SL. S-100 antigen-positive folliculostellate cells are not the source of IL-6 gene expression in human pituitary adenomas. J Neuroendocrinol. 1995; 7:467-474.

30. Arzt E, Buric R, Stelzer G, Stalla J, Sauer J, Renner U and Stalla GK. Interleukin involvement in anterior pituitary cell growth regulation: effects of IL-2 and IL-6. Endocrinology. 1993; 132:459-467.

31. Pereda MP, Goldberg V, Chervin A, Carrizo G, Molina A, Andrada J, Sauer J, Renner U, Stalla GK and Arzt E. Interleukin-2 (IL-2) and IL-6 regulate c-fos protooncogene expression in human pituitary adenoma explants. Mol Cell Endocrinol. 1996; 124:33-42.

32. Kuilman T, Michaloglou C, Vredeveld LC, Douma S, van Doorn R, Desmet CJ, Aarden LA, Mooi WJ and Peeper DS. Oncogene-induced senescence relayed by an interleukin-dependent inflammatory network. Cell. 2008; 133:1019-1031.

33. Arzt E. gp130 cytokine signaling in the pituitary gland: a paradigm for cytokine-neuro-endocrine pathways. J Clin Invest. 2001; 108:1729-1733.

34. Graciarena M, Carbia-Nagashima A, Onofri C, PerezCastro C, Giacomini D, Renner U, Stalla GK and Arzt E. Involvement of the gp130 cytokine transducer in MtT/S pituitary somatotroph tumour development in an autocrineparacrine model. Eur J Endocrinol. 2004; 151:595-604.

35. Paez-Pereda M, Kovalovsky D, Hopfner U, Theodoropoulou M, Pagotto U, Uhl E, Losa M, Stalla J, Grubler Y, Missale C, Arzt E and Stalla GK. Retinoic acid prevents experimental Cushing syndrome. J Clin Invest. 2001; 108:1123-1131.

36. Heaney AP, Fernando M and Melmed S. PPAR-gamma receptor ligands: novel therapy for pituitary adenomas. J Clin Invest. 2003; 111:1381-1388.

37. Lee EJ and Jameson JL. Cell-specific Cre-mediated activation of the diphtheria toxin gene in pituitary tumor cells: potential for cytotoxic gene therapy. Hum Gene Ther. 2002; 13:533-542.

38. Ahmed EK, Rogowska-Wrzesinska A, Roepstorff P, Bulteau $\mathrm{AL}$ and Friguet B. Protein modification and replicative senescence of WI-38 human embryonic fibroblasts. Aging Cell. 2010; 9:252-272.

39. Chen JH and Ozanne SE. Deep senescent human fibroblasts show diminished DNA damage foci but retain checkpoint capacity to oxidative stress. FEBS Lett. 2006; 580:6669-6673.

40. Narita M, Narita M, Krizhanovsky V, Nunez S, Chicas A, Hearn SA, Myers MP and Lowe SW. A novel role for high-mobility group a proteins in cellular senescence and heterochromatin formation. Cell. 2006; 126:503-514.

41. Chesnokova V, Zonis S, Zhou C, Ben-Shlomo A, Wawrowsky K, Toledano Y, Tong Y, Kovacs K, Scheithauer B and Melmed $\mathrm{S}$. Lineage-specific restraint of pituitary gonadotroph cell adenoma growth. PLoS One. 2011; 6:e17924. 
42. Zhou C, Jiao Y, Wang R, Ren SG, Wawrowsky K and Melmed S. STAT3 upregulation in pituitary somatotroph adenomas induces growth hormone hypersecretion. J Clin Invest. 2015; 125:1692-1702.

43. Wolf J, Rose-John S and Garbers C. Interleukin-6 and its receptors: a highly regulated and dynamic system. Cytokine. 2014; 70:11-20

44. Heinrich PC, Behrmann I, Haan S, Hermanns HM, MullerNewen G and Schaper F. Principles of interleukin (IL)6-type cytokine signalling and its regulation. Biochem J. 2003; 374:1-20.

45. Auernhammer CJ, Chesnokova V, Bousquet C and Melmed S. Pituitary corticotroph SOCS-3: novel intracellular regulation of leukemia-inhibitory factormediated proopiomelanocortin gene expression and adrenocorticotropin secretion. Mol Endocrinol. 1998; 12:954-961.

46. Auernhammer CJ and Melmed S. Interleukin-11 stimulates proopiomelanocortin gene expression and adrenocorticotropin secretion in corticotroph cells: evidence for a redundant cytokine network in the hypothalamopituitary-adrenal axis. Endocrinology. 1999; 140:1559-1566.

47. Koyama C, Matsumoto H, Sakai T, Wakabayashi K, Ito A, Couch EF and Inoue K. Pituitary Folliculo-Stellate-Like Cells Stimulate Somatotroic Pituitary Tumor Growth in Nude Mice. Endocr Pathol. 1995; 6:67-75.

48. Ezzat S, Asa SL, Couldwell WT, Barr CE, Dodge WE, Vance ML and McCutcheon IE. The prevalence of pituitary adenomas: a systematic review. Cancer. 2004; 101:613-619.

49. Asa SL and Ezzat S. The pathogenesis of pituitary tumors. Annu Rev Pathol. 2009; 4:97-126.

50. Melmed S. Mechanisms for pituitary tumorigenesis: the plastic pituitary. J Clin Invest. 2003; 112:1603-1618.

51. Scheithauer BW, Gaffey TA, Lloyd RV, Sebo TJ, Kovacs KT, Horvath E, Yapicier O, Young WF, Jr., Meyer FB, Kuroki T, Riehle DL and Laws ER, Jr. Pathobiology of pituitary adenomas and carcinomas. Neurosurgery. 2006; 59:341-353; discussion 341-353.

52. Dworakowska D and Grossman AB. The pathophysiology of pituitary adenomas. Best Pract Res Clin Endocrinol Metab. 2009; 23:525-541.

53. Farrell WE. Epigenetics of pituitary tumours: an update. Curr Opin Endocrinol Diabetes Obes. 2014; 21:299-305.

54. Yacqub-Usman K, Duong CV, Clayton RN and Farrell WE. Epigenomic silencing of the BMP-4 gene in pituitary adenomas: a potential target for epidrug-induced re-expression. Endocrinology. 2012; 153:3603-3612.

55. D'Angelo D, Esposito F and Fusco A. Epigenetic Mechanisms Leading to Overexpression of HMGA Proteins in Human Pituitary Adenomas. Front Med. 2015; 2:39.

56. Fedele $\mathrm{M}$ and Fusco A. Role of the high mobility group A proteins in the regulation of pituitary cell cycle. J Mol Endocrinol. 2010; 44:309-318.
57. Hanisch A, Dieterich KD, Dietzmann K, Ludecke K, Buchfelder M, Fahlbusch R and Lehnert H. Expression of members of the interleukin- 6 family of cytokines and their receptors in human pituitary and pituitary adenomas. J Clin Endocrinol Metab. 2000; 85:4411-4414.

58. Borg SA, Kerry KE, Baxter L, Royds JA and Jones TH. Expression of interleukin-6 and its effects on growth of HP75 human pituitary tumor cells. J Clin Endocrinol Metab. 2003; 88:4938-4944.

59. Fauquier T, Rizzoti K, Dattani M, Lovell-Badge R and Robinson IC. SOX2-expressing progenitor cells generate all of the major cell types in the adult mouse pituitary gland. Proc Natl Acad Sci U S A. 2008; 105:2907-2912.

60. Vankelecom H and Gremeaux L. Stem cells in the pituitary gland: A burgeoning field. Gen Comp Endocrinol. 2010; 166:478-488.

61. Drouin J, Bilodeau S and Roussel-Gervais A. Stem cells, differentiation and cell cycle control in pituitary. Front Horm Res. 2010; 38:15-24.

62. Garcia-Lavandeira M, Quereda V, Flores I, Saez C, DiazRodriguez E, Japon MA, Ryan AK, Blasco MA, Dieguez C, Malumbres M and Alvarez CV. A GRFa2/Prop1/stem (GPS) cell niche in the pituitary. PLoS One. 2009; 4:e4815.

63. Nagai $\mathrm{Y}$, Aso H, Ogasawara H, Tanaka S, Taketa Y, Watanabe K, Ohwada S, Rose MT, Kitazawa H and Yamaguchi T. Anterior pituitary progenitor cells express costimulatory molecule 4Ig-B7-H3. J Immunol. 2008; 181:6073-6081.

64. Vankelecom H. Non-hormonal cell types in the pituitary candidating for stem cell. Semin Cell Dev Biol. 2007; 18:559-570.

65. Horvath E, Coire CI, Kovacs K and Smyth HS. Folliculostellate cells of the human pituitary as adult stem cells: examples of their neoplastic potential. Ultrastruct Pathol. 2010; 34:133-139.

66. Andoniadou CL, Matsushima D, Mousavy Gharavy SN, Signore M, Mackintosh AI, Schaeffer M, Gaston-Massuet C, Mollard P, Jacques TS, Le Tissier P, Dattani MT, Pevny LH and Martinez-Barbera JP. Sox2(+) stem/progenitor cells in the adult mouse pituitary support organ homeostasis and have tumor-inducing potential. Cell Stem Cell. 2013; 13:433-445.

67. Inoue $\mathrm{K}$, Hattori M, Sakai T, Inukai S, Fujimoto $\mathrm{N}$ and Ito A. Establishment of a series of pituitary clonal cell lines differing in morphology, hormone secretion, and response to estrogen. Endocrinology. 1990; 126:2313-2320.

68. Inoue K, Matsumoto H, Koyama C, Shibata K, Nakazato Y and Ito A. Establishment of a folliculo-stellate-like cell line from a murine thyrotropic pituitary tumor. Endocrinology. 1992; 131:3110-3116.

69. Windle JJ, Weiner RI and Mellon PL. Cell lines of the pituitary gonadotrope lineage derived by targeted oncogenesis in transgenic mice. Mol Endocrinol. 1990; 4:597-603. 
70. Thiele JO, Lohrer P, Schaaf L, Feirer M, Stummer W, Losa M, Lange M, Tichomirowa M, Arzt E, Stalla GK and Renner U. Functional in vitro studies on the role and regulation of interleukin-6 in human somatotroph pituitary adenomas. Eur J Endocrinol. 2003; 149:455-461.

71. Shan B, Gerez J, Haedo M, Fuertes M, Theodoropoulou M, Buchfelder M, Losa M, Stalla GK, Arzt E and Renner U.
RSUME is implicated in HIF-1-induced VEGF-A production in pituitary tumour cells. Endocr Relat Cancer. 2012; 19:13-27.

72. Debacq-Chainiaux F, Erusalimsky JD, Campisi J and Toussaint O. Protocols to detect senescence-associated beta-galactosidase (SA-betagal) activity, a biomarker of senescent cells in culture and in vivo. Nat Protoc. 2009; 4:1798-1806. 